\title{
Authentic Learning: Bridging the Gap of Knowledge and Action in South African Higher Education
}

\author{
Hlaviso A. Motlhaka \\ University of the Free State, School of Social Science and Language Education, RSA \\ motlhakaha@ufs.ac.za
}

\section{Doi:10.5901/mjss.2014.v5n23p891}

\begin{abstract}
This article addresses the issue of authentic learning as a pedagogical approach in South African university in the Free State Province to bridge the gap of knowledge and action for meaningful teaching and learning of English as a Second Language (ESL). The aim of the study was to investigate the connection between authentic learning and problem-based learning in the hope of establishing effective strategies of teaching ESL. The researcher used qualitative research approach with phenomenological research design. The research population of this study encompassed eight first-year students and eight ESL lecturers with less than six years teaching experience in the faculty of education at an institution of higher learning and information was gathered through the use of open-ended questionnaires and focus group interviews. The findings found that technology has a profound impact on authentic learning in Higher Education because it gives students access to reliable, firsthand information for investigation and analysis, as well as a larger real-world audience outside the classroom. This article also finds that authentic learning recognizes students as legitimate peripheral participants in a community of practice to be competitive in a global job market. Finally, it outlines the roles of the lecturer as a nurturer and innovator who strives to broaden student learning experiences through sharing with the world outside the school walls and provides recommendations to help lecturers and researchers in enhancing students' ESL learning through the use of authentic learning paradigm.
\end{abstract}

Keywords: Authentic learning, problem-based learning, real-life topics, popular culture, technology

\section{Introduction and Background}

Through the use of authentic learning as a pedagogical approach, students are able to explore, discuss and construct meaningful concepts in real-world context relevant to them (Donovan, Bransford, \& Pellegrino, 1999). The goal of authentic learning is to allow students to express their preferences of learning by doing rather than by listening as they engage in genuine English as a Second Language (ESL) learning which presents them with the opportunity to make direct connections between new material and their prior knowledge, and what is expected of them outside the classroom. Authentic learning provides a bridge to the separation of knowledge and action. It allows students to express their preferences of learning by doing rather than by listening as they engage in a genuine learning which presents them with the opportunity to make direct connections between new material and their prior knowledge. Authentic learning helps undergraduate students to realize that their achievements are not only limited in the classroom but go beyond the classroom. In this case, authentic learning provides undergraduate students with a means to bridge their experiences, knowledge, beliefs and learning curiosities into the classroom to trigger their intrinsic motivation when engaged in-service learning, apprenticeship, cooperative learning, job-shadowing and internship experiences among others (Cavanaugh, 2004). Undergraduates are therefore gaining a deeper sense of the discipline as a special "culture" which shapes their specific ways of seeing and interpreting the world in a problem-based learning (PBL) use on a daily basis (Lombardi, 2007). Problem-based learning is considered a highly motivational method of learning when integrated with authentic learning because it offers students with opportunities to complete the learning tasks and identify areas for improvement in their own reasoning ability.

The effectiveness of PBL on student engagement through authentic learning could be realized when students are challenged academically and intensely within a supportive environment that provides multiple opportunities for realistic problems and authentic assessment. This view is supported by the Curriculum and Assessment Policy Statement (CAPS) in South Africa which strives for students to identify and solve problems and make decisions using critical and creative thinking through active participation in the learning process (CAPS, 2011). It is therefore advisable to ESL lecturers at institutions of higher learning to incorporate authentic pedagogy in the classroom to create graduates that are more equipped with problem-solving skills and creative thinking skills. According to Neo, Neo and Tan (2012) an ESL content 
should be designed as authentic as possible by incorporating content and activities that reflect real-life situations in which students become active participants in the learning process. This type of learning exposes students to multiple perspectives solutions to their learning problems, hence, authentic learning focuses on real-world, complex problems and their solutions and problem-based activities. In this case, authentic learning allows students to experience real-world problems while in a learning environment enables them to become legitimate members of a community of practice (Neo, Neo \& Tan, 2012). On the other hand, integration of technology with authentic learning offers students opportunities to communicate and collaborate with experts and access data for experiments and study. For instance, Internet allows virtual experiences when real world experiences are not possible and provides a means of communication with other students around the world. It can therefore be concluded that authentic learning facilitates the transition of students from education institutions to the workplace where students apply theoretical knowledge into real context for the development of their cognitive, social and affective behaviours.

\section{Theoretical Framework}

This study adopts problem-based learning (PBL) as a theoretical framework because it is derived from a theory that suggests effective acquisition of knowledge, wherein students need to be stimulated to restructure information known within a realistic context to gain new knowledge. This theory is relevant to this study because it improves student performance on complex tasks and fosters better retention of knowledge through real-life context (Allen, Donham \& Bernhardt, 2011).

\section{Research Problem}

One of the most challenging tasks facing ESL lecturers is how to capture and stimulate students' interest, motivation and attention to learn beyond the classroom. Another challenge for lecturers is choosing appropriate learning materials and activities relevant to students' linguistic and cultural component in the ESL classroom. As a result, lack of lecturers' experience to successfully implement authentic learning method to bridge the gap of knowledge and action for meaningful acquisition of knowledge beyond the classroom has a negative impact on students' overall academic success due to the use of ESL across university curriculum.

\section{Research Questions}

The main research questions in this study were:

- How do students respond to the use of authentic learning paradigm in the classroom and beyond?

- How do students view authentic learning and problem-based learning as tool for motivation and enhancing their knowledge of ESL?

\section{Aim of the Study}

Given the growing popularity of authentic learning in higher education, this study seeks to explore the connection between authentic learning and problem-based learning in the hope of establishing effective strategies of teaching ESL.

\section{Objectives of the Study}

In order to achieve the aim of this study, the following objectives have been formulated:

- To examine ESL students' and lecturers' perceptions concerning the use of authentic learning and problembased learning.

- To identify effective strategies ESL lecturers would use through authentic learning.

- Explore the implications of authentic learning paradigm and problem-based learning in an English (ESL) classroom.

\section{Significance of the Study}

This study was designed to present implications specific to lecturers who are interested to use authentic learning paradigm as a vehicle to bridge the gap of knowledge and action for meaningful ESL acquisition of knowledge beyond the 
classroom.

\section{Research Methodology}

In this research study, the researcher used qualitative approach which is used for in depth investigations to develop an understanding of individuals and events in their natural state. Qualitative research represents an inquiry about a field and to explore the participants' experiences and understanding of these experiences (Creswell, 2008). Study was conducted in a natural setting in which students and lecturers were asked questions to answer based on their views on authentic learning paradigm and data collected emanated from open-ended questionnaires and focus-group interviews because the researcher wanted to gather in-depth information about students' and lecturers' views on the use authentic learning paradigm and their roles during their lectures.

\section{Research Design}

The research design used in this study was phenomenological research design where the researcher forms part of the day-to-day life of his/her population in gathering data (Criticos, 2002). The researcher in this study works in the institution where he collects data and this gives the researcher the opportunity to interact with students and lecturers in order to gather information on the use of authentic learning paradigm. A phenomenological research paradigm is a study that gives the researcher the opportunity to understand participants' perceptions, perspectives and understandings on use of authentic learning paradigm.

\section{Population and Sampling}

The research population of this study encompassed eight first-year students and eight ESL lecturers with less than six years teaching experience in the faculty of education at an institution of higher learning. All participants were given openended questionnaires and volunteered to participate in the focus group interviews.

\section{Data Collection and Instruments}

Overall, data collection in qualitative research is collected in its natural setting (Holliday, 2001). Information was gathered through the use of open-ended questionnaires and focus group interviews of students and lecturers.

\section{Data Analysis}

The analysis of qualitative research involves aiming to uncover and understand participants perceptions and perspectives by using the data to describe the phenomenon and what this means. This understanding was organized in accordance of recurring themes and used them as headings for sections in a document on the computer as a draft for analysis. Finally, data collected from taped recorded interviews was transcribed verbatim and summarizing the salient aspects.

\section{Trustworthiness}

The trustworthiness of a qualitative study can be increased by maintaining high credibility and objectivity. In order to maintain high trustworthiness in a qualitative study, the researcher used Krefting's (1991) four criteria to ensure valid interpretation of data: truth value, applicability, consistency, and neutrality. In the qualitative approach, truth value is measured by credibility by having an adequate engagement in the research setting so recurrent patterns in data can be properly identified and verified hence the researcher works in the university where data was collected. Applicability is established with transferability by allowing readers to be able to apply the findings of the study to their own situations, be it nationally or internationally in other universities.

\section{Ethical Considerations}

In the light of the established codes of ethics, the researcher has responsibilities to the research participants. Overall, data collection was governed by the code of conduct that the consequence of participating in a study does not harm the participants in any way and intimate information should not be disclosed during the data collection process (Creswell, 
2007, Frankel \& Wallen, 2000). Therefore, interactive research ethical issues were considered prior to data collection in order to recognize and protect the rights of participants. The researcher used consent forms where the participants signed as a way of voluntarily agreeing to participate in the research.

In addition, in this study the researcher took the following steps to safeguard the research participants:

1. The researcher communicated the aims of the research to those participating in the study.

2. The researcher explained to the participants that their participation is valuable but dependent on their agreement to participate willingly.

3. In an attempt to minimize place threats, the researcher conducted interviews privately with each student and lecturer in a convenient vacant room on campus.

4. The researcher asked for permission to record interviews from each participant and state that the information was for research purpose only.

5. The researcher kept the participants' names and university confidential.

\section{Results and Discussion}

The purpose of this study was to investigate the connection between authentic learning and problem-based learning in the hope of establishing effective strategies of teaching ESL and to improve ESL lecturers' teaching practice to bridge the gap of knowledge and action for meaningful ESL acquisition of knowledge beyond the classroom. The discussion of the results of this study is presented through the category of the development of authentic learning with the following subcategories: Role of lecturers in authentic learning, real-life topics, entertainment and humor, popular culture, emotional attachment and involvement, and implication of authentic learning in the classroom.

\subsection{Role of lecturers in authentic learning}

The lecturer is considered the critical ingredient in the process of teaching and learning through the use authentic learning. The study found that lecturers should know how to assess students' strengths and weaknesses when designing lessons. This finding suggests that lecturers will then be able guide students upon building on their prior knowledge in providing students with rich resources to utilize for their acquisition of knowledge and broadening students' learning experiences to share with the world outside the school walls.

\subsection{Real-life topics}

A significant benefit of authentic learning is its ability to expose students to images of daily-life that are typical to the topic which has been linked to student interest and motivation. This tendency was attributed to the belief that real-life knowledge allows students to more easily identify with and make connections between target language and their home language. In this situation, sociolinguistic is appropriate to authentic media because it is considered appealing to students as it allows them to see and hear how the target language is spoken in real situation and shows them how people act. The study finds that real-life topics are encouraged in the earlier stages of instruction because information learned by students in class is geared towards everyday topics they encounter outside the classroom. For instance, teaching students about applying for jobs using real job applications and have them practice filling them out in class and also conducting job interviews using real-life interview questions. This type of practice will not only teach students the vocabulary they should know in responding to interview questions, but also boost their confidence. It was also found that real-life topics keep students on their toes and creates an excitement and fun for effective teaching of ESL components as long as they can see a direct personal benefits and life relevancy in what they are taught in school (Cheung, 2001). It is therefore imperative for ESL lecturers to encourage their students to bring into the classroom their own samples of authentic language data from real-world contexts outside of the classroom wherein they practice listening and reading of genuine language drawn from many different sources, including TV and radio broadcasts, taped conversations, meetings, talks, and announcements.

\subsection{Entertainment and humor}

Several studies have found that entertainment is an instrumental factor in the successful use of authentic media in a language class because it maintains higher level of interest among language students (Ishihara, 2004). For instance, this study found that ESL learning is much easier if commercial is comedic because it keeps students' interests and attention 
when people are making jokes even if they are not interested in the product, but makes them to smile at the joke and think of what they were saying. According White (2000) students prefer in engaging in video material rather than texts because the language is brought alive to contribute to a positive orientation to the language.

Humor in the classroom attracts attention and provokes thought, liberates creative capacities, helps gain friends, improves communication, soothes difficult moments, develops a positive attitude and self-image, motivates and energizes, solves problems, increases quality and quantity of students' reading, reinforces desired behaviors, and has entertainment value (Garner, 2006; Glenn, 2002, Berk, 1998). It can therefore be concluded humor helps students to analyze their own sense of humor, use humor appropriately in social situations, and speak and write creatively. It also enables lecturers to help students analyze their own sense of humor, use humor appropriately in social situations, and speak and write creatively. This finding indicates the significance of entertainment and humor in language learning which provides students with the potential of a non-threatening and enjoyable environment with a low anxiety level due to lack of assessment.

\subsection{Popular culture}

Popular culture deals with students' attitudes and feelings of daily life by bridging the gap between formal and informal ESL learning because students can easily identify with the popular culture of the target language. Intertextuality involving popular culture is a powerful resource for displaying, maintaining lecturers' and students' disparate social and cultural identities and networks for successful ESL learning and teaching (Duff, 2002). This study reveals that most students and their families subscribe to daily English newspapers and watch local news channel at dinnertime, which actually makes an immense impact on ESL learning because almost all students are able to participate in the discussion. Furthermore, the study found that most ESL students use WhatsApp Messenger, a cross-platform mobile messaging app which allows them to exchange messages without having to pay for SMS that links up groups of friends for spontaneous online discussion about any topic, including popular culture. Finally, this study finds that more explicit work needs to be done to raise lecturers' and students' awareness on the significant elements that underpins popular culture from different backgrounds regarding construction of knowledge, social and cultural identities to understand sociolinguistic and semiotic forms and functions of texts.

\subsection{Emotional attachment and involvement}

Emotional attachment in authentic learning through the use of movies in an ESL class is found to be a key factor in engaging and provoking students' interest and attention. The study found that when students are emotionally attached to the characters tend to enjoy how the movie presents people in real-life situation in using the target language in an informal environment. The emotional attachment to the storyline and the characters results in positive feelings among ESL students from having been exposed to the target language and its culture. Students involved in the learning activities show behavioural involvement and positive emotional tone such as enthusiasm, optimism, curiosity and interest in the implementation of the tasks (Skinner \& Belmont, 1993). This study shows that students who are more attached and involved in authentic learning select tasks that are beyond their competencies and show better adjustment in an ESL classroom. According to the findings of this study, emotional attachment provides students with the feelings of security and a need to explore learning opportunities freely as they strive to balance their innate motivation.

\section{Conclusion}

The findings of this study indicate that authentic learning is resourceful pedagogy that enables students to interact with the real language and content rather than the form. Thus, students feel that they are learning a target language as it is used outside the classroom rather than get exposure of the target language in the classroom only. The finding suggests that authentic learning should be used at any level of ESL learning to complete the gap between the competency and performance of ESL students, which is a common problem among the non-native speakers. Furthermore, the findings in this study suggest that authentic learning provides a viable opportunity to incorporate interesting and enjoyable tasks in an ESL class. These tasks maintain and encourage intrinsic motivation among ESL students at the earliest stages of language learning. The study found that in an authentic learning environment, real-life topics, emotional involvement and entertainment stimulate students' eagerness and curiosity about what life is like outside the classroom and create a nonthreatening environment in which students are more comfortable to experience and practice the target language. The use of popular culture in authentic learning environment was also found to be more stimulating as it presents students with 
opportunities to explore topics that are relevant to them in order to bridge the gap between formal and informal English learning. Lecturers are therefore encouraged to use popular culture as a motivating tool to help students connect new materials to their present knowledge (Cheung, 2001). This study also suggests that appropriate use of humour and entertainment in an ESL classroom have a positive impact on student enjoyment and content retention. Therefore, this study recommends that lecturers should be encouraged to consider the use media as a valuable learning tool in their ESL curricula. This recommendation is underpinned by the overspread adoption and accessibility of iPod media players, media-enabled cell phones, and web-based video services such as YouTube among others to university students to discover, experience and explore these new technologies for language learning.

\section{References}

Allen, D. E, Donham, R.S, \& Bernhardt, S.A. (2011). Problem-based learning. New Direction for Teaching and Learning, 28, 21-29.

Berk, R. (1998). Professors are from Mars, students are from Snickers. Madison, WI: Mendota.

Creswell, J. W. (2008). Educational Research: planning, conducting and evaluating quantitative and qualitative research, New Jersey: Pearson education. Education, 28, 203-219.

Creswell, J. W. (2007). Research design: Qualitative, Quantitative and Mixed Methods Approaches. 3rd Edition. London: SAGE.

Criticos, C. (2002). Getting Practical. 2nd edition. Oxford University of Press: Cape Town.

Donovan, M. S., Bransford, J. D., \& Pellegrino, J. W. (1999). How people learn: Bridging research and practice. Washington, DC: National Academy Press.

Duff, P. A. (2002). Pop culture and ESL students: Intertextuality, identity, and participation in classroom discussions. Journal of Adolescent \& Adult Literacy, 45(6), 482-487.

Frankel, J. R., \& Wallen, N. E. (2000). Exploring research (4thed.). New York: Prentice Hall.

Garner, R. L. (2006). Humor in Pedagogy: How Ha-Ha Can Lead to Aha! College Teaching, 54(1), 177-180.

Glenn, R. (2002). Brain research: Practical applications for the classroom. Teaching for Excellence, 21(6), 1-2.

Krefting L. (1991). Rigor in qualitative research: the assessment of trustworthiness. Am J Occup Ther. 45(3), 214-222.

Ishihara, N., Chi, J. (2004). Authentic Video in the Beginning ESOL Classroom: Using a Full-Length Feature Film for Listening and Speaking Strategy Practice. English Teaching Forum, January, 30-35.

Neo, M., Neo, K.T., \& Tan, H.Y. (2012). Applying authentic learning strategies in a multimedia and web learning environment (MWLE): Malaysian students' perspective. The Turkish Online Journal of Educational Technology, 11(3), 50-60.

Skinner, E. A., \& Belmont, M. J. (1993). Motivation in the classroom: Reciprocal effects of teachers behavior and student engagement across the school year. Journal of Educational Psychology, 85(4), 571-581.

White, C., Easton, P., \& Anderson, C. (2000). Students' Perceived Value of Video in a Multimedia Language Course. Educational Media International, 37(3), 167-175. 